\title{
Comparison of nonlinear models for the description of carbon mineralization in soils treated with pig slurry
}

Gustavo Sérgio de Paula ${ }^{1}$

Edilson Marcelino Silva²

Thais Destefani Ribeiro Furtado 3

Ariana Campos Frühauf ${ }^{4}$

Joel Augusto Muniz ${ }^{5}$

\section{Abstract}

One of the strategies to reduce environmental impacts caused by pig slurry is its application to soils for agricultural productions. Carbon mineralization curves can be used to determine the best periods for the use of organic matter for an adequate management of soils and growing plants. The objective of this study was to evaluate the fit of nonlinear models for soil carbon mineralization. The experiment was conducted using a randomized block design with four replications and four treatments. The treatments consisted of monthly applications of pig slurry at rates of $0,7.5,15.0$, and $30.0 \mathrm{~m}^{3}$ ha $^{-1}$ of pig slurry. Soil samples were collected and incubated for 26 days; then, seven observations of mineralized carbon volume were made over time. The description of the carbon mineralization followed the Stanford and Smith, Cabrera, and Juma models, considering the structure of autoregressive errors AR (1), when necessary; the fits were compared using the Akaike Information Criterion (AIC). The description of carbon mineralization in the treatments by nonlinear models was, in general, adequate. Juma was the most adequate model to describe the treatment with rate of 0 . Stanford and Smith was the most adequate model to describe the treatments with rates of 7.5 and $15.0 \mathrm{~m}^{3} \mathrm{ha}^{-1}$. Cabrera was the most adequate model to describe the treatment with rate of $30.0 \mathrm{~m}^{3} \mathrm{ha}^{-1}$.

Keywords: Organic waste. Stanford and Smith model. Cabrera model. Juma model.

\section{Introduction}

Pig production is relevant in the Brazilian agrobusiness due to the high number of people employed in this production chain and the expressive generation of income for producers and exports to the country. Brazil is the fourth largest pig meat producer and exporter country (CONAB, 2017; GUIMARÃES et al., 2017). Its high pig production generates a large amount of liquid wastes, which can cause several environmental problems when not appropriately used or disposed, such as contamination of water bodies and public health problems due to the release of substances, such as nitrate in water courses (CADONÁ, 2017).

\footnotetext{
1 Universidade Federal de Lavras (UFLA), graduando em Agronomia. gustavo.paula1@agronomia.ufla.br. Departamento de Estatística, Campus Universitário da UFLA, Lavras, Minas Gerais, CEP 37200-000.

2 UFLA, doutorando em Estatística e Experimentação Agropecuária. edilsonmg3@hotmail.com.

3 UFLA, doutoranda em Estatística e Experimentação Agropecuária. t.destefani.ribeiro@gmail.com.

4 UFLA, doutoranda em Estatística e Experimentação Agropecuária. arianafruhauf@gmail.com.

5 UFLA, professor titular. joamuniz@des.ufla.br.
} 
However, an alternative for the use of pig slurry to decrease its environmental impacts is its use as a source of nutrients to agricultural crops. The chemical composition of pig slurry includes a large amount of nitrogen, which is required in large amounts by plants (BISON PINTO et al., 2014). Moreover, the input of organic compounds to the soil stimulates the growth of microorganism populations, resulting in carbon immobilization or mineralization as carbon dioxide; and the amount and quality of the substrate and its interaction with the soil microbiota can result in mineralization of the native soil organic matter (FERNANDES et al., 2011).

Several factors affect the decomposition process of organic compounds in the soil, such as the relation between the compound $\mathrm{pH}$ and soil $\mathrm{pH}$, the compound chemical composition, the amount of carbon, the $\mathrm{C}$ to $\mathrm{N}$ ratio, and the form of application to the soil (e.g. incorporation). Most of the carbon mineralization occurs, in general, at the beginning of the decomposition of organic compounds in the soil because of a greater soluble fraction with labile compounds in this period; when this fraction decreases, the mineralization is slower because of the more resistant compounds to microorganisms (GIACOMINI et al., 2008). This dynamic of the mineralization curve can be described by mathematical functions that constitute nonlinear regression models (FERNANDES et al., 2011; SILVA et al., 2019a).

Thus, studying carbon mineralization curves over time is important and necessary to understand the decomposition dynamics of organic compounds that can assist in more favorable soil management practices for agricultural production. Nonlinear models are used to describe carbon mineralization curves; they provide a good fit and gather the information contained in the data into few parameters, providing estimates with biological and practical interpretations, which are useful to rural producers (SILVEIRA et al., 2018).

One of the most used nonlinear models to describe soil carbon mineralization over time is the Stanford and Smith (1972). This model was used in several studies on dynamics of carbon, presenting good results in researches on eucalyptus plantations (BARRETO et al., 2010), tannery sludge (MARTINES et al., 2006), septic tank sludge, anaerobic digestor sludge, reactor sludge (SILVA, 2017), carcass and residue of small ruminants (PEREIRA, 2014), pig slurry and oat plant residues (SILVA et al., 2019a), and sewage sludge and oat plant residues (SILVA et al., 2019b).

In studies on nonlinear models with measures in the same experimental unities over time, observations normally present correlations, which also occurs in studies of decompositions in soils (SILVA et al., 2019a), presenting structures of dependence in the experimental errors. According to Silveira et al. (2018), considering the modeling of this correlation is necessary to obtain an appropriate fit.

The objective of the present work was to evaluate the fit of nonlinear regression Models Cabrera (1993), Juma et al. (1984), and Stanford and Smith (1972) for the description of carbon mineralization in soils from the $2^{\text {nd }}$ to the $26^{\text {th }}$ day after pig slurry application, and to identify the most adequate model to describe the dynamics of decomposition of organic compounds in the soil.

\section{Material and methods}

The data used to fit the models were extracted from Fernandes et al. (2011) and correspond to mean results of an experiment that evaluated carbon mineralization in soils using different rates of pig slurry. The experiment was conducted in São Gabriel do Oeste, MS, Brazil. The soil of the area was classified as a Typic Hapludox (Latossolo Vermelho Distrófico - SiBCS); it was covered with pastures 
for bovine milk production. Soil samples were collected from the 0-10 cm layer. The pig slurry used consisted of feces and urine, feed leftovers, and water from the drinkers and cleaning processes.

The experiment was conducted in a randomized block experimental design, with four treatments and four replications. The treatments consisted of monthly applications of pig slurry at rates of $0,7.5$, 15.0, and $30.0 \mathrm{~m}^{3} \mathrm{ha}^{-1}$ of pig slurry. The carbon mineralization (C) data was obtained in laboratory conditions by measuring the $\mathrm{C}$ released by the soil microbial activity as carbon dioxide $\left(\mathrm{CO}_{2}\right)$. The soil samples were air dried and sieved (2.0 mm mesh). Aliquots of $50.0 \mathrm{~g}$ of soil were placed in 100.0-ml flasks. The soil moisture was corrected to $60.0 \%$ of maximum water retention capacity. The amount of mineralized carbon was evaluated after $2,6,9,13,16,22$, and 26 days of incubation.

The nonlinear models evaluated were: Cabrera (1), Juma (2), and Stanford and Smith (3), according to the following equations:

$$
\begin{gathered}
C_{i}=C_{1}\left(1-\exp \left(-k_{1} t_{i}\right)\right)+k_{0} t_{i}+u_{i} \\
C_{i}=C_{0} t_{i} /\left(v+t_{i}\right)+u_{i} \\
C_{i}=C 0\left(1-\exp \left(-k t_{i}\right)\right)+u_{i}
\end{gathered}
$$

at which

$\mathrm{u}_{\mathrm{i}}=\phi_{1} \mathrm{u}_{\mathrm{i}-1}+\ldots+\phi_{\mathrm{p}} \mathrm{u}_{\mathrm{i}-\mathrm{p}}+\varepsilon_{\mathrm{i}}$, with $i=1,2, \ldots, \mathrm{n}$ ( $\mathrm{n}=$ number of evaluation times);

$\mathrm{u}_{\mathrm{i}}$ is the residue of the fit in the $i$ th time;

$\phi_{1}$ is the autoregressive parameter of order 1 ;

$\mathrm{u}_{\mathrm{i}-1}$ is the residue of the fit of the preceding time to the ith measure;

$\phi_{\mathrm{p}}$ is the autoregressive parameter of order $\mathrm{p}$;

$\mathrm{u}_{\mathrm{i}-\mathrm{p}}$ is the residue of the fit in the $\mathrm{p}$ times before the ith measure;

$\varepsilon_{\mathrm{i}}$ is the experimental error, with normal distribution with mean zero and variance $\sigma^{2}$, e. g., $\varepsilon_{i \sim} N\left(0, \sigma^{2}\right)$.

When the residues in the models were independent, the parameters $\phi_{\mathrm{i}}$ were null and, consequently, $u_{i}=\varepsilon_{i}$ (MAZZINI et al., 2003; GUEDES et al., 2004, SAVIAN et al., 2007; MENDES et al., 2008; PRADO et al., 2013; SOUZA et al., 2014).

The $C_{i}$ in the equations (1), (2), and (3) defines the mean value of the amount of mineralized carbon in the times $\mathrm{t}_{\mathrm{i}}$ in days; $\mathrm{C}_{0}$ indicates the value of the amount of potentially mineralizable carbon; $C_{1}$ is the amount of easily mineralizable carbon; $k, k_{1}, k_{0}$ are mineralization rates; $v$ is the half-life time; $t_{i}$ is the time of the ith evaluation, expressed in days (PEREIRA et al., 2005; PEREIRA et al., 2009). The half-life time (v) of potentially mineralizable carbon for the Stanford and Smith model, and of easily mineralizable carbon for the Cabrera model was estimated by $v=\ln (2) / k$, and $v=\ln (2) / k_{1}$, respectively. When the parameter $k_{0}$ of the Cabrera model was zero, the model became the Stanford and Smith model. Moreover, the Cabrera model considers two carbon fractions: an easily mineralizable $\left(\mathrm{C}_{1}\right)$ and a resistant $\left(\mathrm{k}_{0}\right)$ fraction. The Juma model and the Stanford and Smith model consider only one carbon fraction: potentially mineralizable fraction $\left(\mathrm{C}_{0}\right)$.

The estimation of the parameters $C_{0}, C_{1}, k, k_{1}, k_{0}$, and $v$ of the models was done using the minimum square method, obtaining the nonlinear normal equation system. In the case of nonlinear models, the system presents no direct solution, and use of iterative algorithms of numerical search is necessary to obtain the estimates of the parameters (CARNEIRO et al., 2014; MUIANGA et al., 
2016). Several iterative processes are described in the literature; the one used in the present work was the Gauss-Newton algorithm (MUNIZ et al., 2017; RIBEIRO et al., 2018a; RIBEIRO et al., $2018 b)$. This algorithm considers the expansion in series of Taylor to approach the nonlinear regression model with linear terms, then, applying the ordinary minimum square method to estimate the parameters. The calculations of estimates for the sampled data, their fit to graphics, and all computational processes involved with the elaboration of this work were developed using the $\mathrm{R}$ program ( $\mathrm{R}$ DEVELOPMENT CORE TEAM, 2016).

Confidence intervals of the estimated parameters were obtained under the supposition of normality of residues. According to Draper and Smith (2014), an interval of 95\% of confidence for the parameter $\beta$ i of the model is defined as:

at which:

$$
\operatorname{IC}\left(\beta_{\mathrm{i}}\right): \mathrm{b}_{\mathrm{i}} \pm \mathrm{t}(\mathrm{v} v ; 0 ; 025) \cdot \mathrm{S}\left(\mathrm{b}_{\mathrm{i}}\right)
$$

$b_{i}$ is the estimate for the parameter $\left(\beta_{i}\right)$;

$\mathrm{S}\left(\mathrm{b}_{\mathrm{i}}\right)$ is the standard error of the estimate;

$t(v ; 0 ; 025)$ is the upper quantile of the Student t distribution, considering $\alpha=5 \%$ and the degrees of freedom $\mathrm{v}=\mathrm{n}-\mathrm{d}$, at which $\mathrm{d}$ is the number of parameters of the model.

The Durbin Watson test was applied to verify the presence of residual dependence between the measures, evaluating if the residue of an observation is associated with the residue of the adjacent observations (FURTADO et al., 2019). The Breusch-Pagam test was used to verify the homogeneity of residues, and the Shapiro-Wilk test was used to verify their normality.

The models were compared for quality of fit, and the most adequate model to describe the $\mathrm{C}$ mineralization curve over time was indicated. The following criteria was used:

$\mathrm{i}$. Adjusted coefficient of determination, $\mathrm{R}^{2}{ }_{\mathrm{aj}}$, defined by:

$$
\mathrm{R}^{2}{ }_{\mathrm{aj}}=1-\frac{\left(1-\mathrm{R}^{2}\right)(\mathrm{n}-1)}{\mathrm{n}-\mathrm{d}}
$$

at which

$\mathrm{R}^{2}$ the coefficient of determination;

$n$ is the number of observations and $d$ is the number of parameters of the model.

A model should be preferred than the other when presenting a higher value of AIC.

ii. Akaike information criterion (AIC) given by the expression:

$$
\mathrm{AIC}=-2 \log \mathrm{L}(\widetilde{\theta})+2 \mathrm{p}
$$

at which

$L(\widetilde{\theta})$ is the maximum of the likelihood function;

$p$ is the number of parameters in the model;

log is the natural logarithm operator. Between two models, the lower the value of AIC, the better the model fits the data. 


\section{Results and discussion}

The results obtained by analysis of experimental errors (TABLE 1) were expressed by the Shapiro-Wilk, Breusch-Pagan, and Durbin-Watson tests. According to the results, the Shapiro-Wilk test indicated residual normality for all models and all treatments evaluated, except for the treatment with pig slurry rate of 0 of the Stanford and Smith model $(p<0.05)$; thus, this model was disregarded, and the estimates of the parameters were not presented, as well as the evaluators of quality of fit of this model for the rate of 0 . The Breusch-Pagan test indicated residual homogeneity for all models and treatments $(p>0.05)$. The Durbin-Watson test showed correlations for all treatments of the Juma model, and for the treatment with rate of $30.0 \mathrm{~m}^{3} \mathrm{ha}^{-1}$ of the Cabrera model; thus, the correlation was considered in the study and the fits with autoregressive errors of order $1 A R(1)$ was presented to explain the dependence of residues of these treatments. This correlation of the errors was expected, since the measures were made in the same plot over time. Silva et al. (2019a) also found correlation for the fit of nonlinear models to data of carbon mineralization from pig slurry; and Silveira et al. (2018) found correlation of errors when fitting nonlinear models to accumulated production of biogas from pig waste. The treatments evaluated by the Stanford and Smith model and Cabrera model presented independence of errors in the pig slurry rates of $0,7.5$, and $15.0 \mathrm{~m}^{3} \mathrm{ha}^{-1}$.

Table 1 - P-values of Shapiro-Wilk (SW), Durbin-Watson (DW), and Breusch-Pagan (BP) tests applied to errors of models for mineralized carbon ( $\mathrm{mg} \mathrm{CO}_{2} \mathrm{~kg}^{-1}$ ) of the evaluated treatments.

\begin{tabular}{ccccc}
\hline $\begin{array}{c}\text { Treatments } \\
\text { (Rate of slurry) }\end{array}$ & Model & $\begin{array}{c}\text { SW } \\
\text { p-value }\end{array}$ & $\begin{array}{c}\text { BP } \\
\text { p-value }\end{array}$ & $\begin{array}{c}\text { DW } \\
\text { p-value }\end{array}$ \\
\hline 0 & Stanford and Smith & 0.0172 & 0.7773 & 0.6880 \\
0 & Cabrera & 0.3564 & 0.2199 & 0.9240 \\
0 & Juma & 0.4946 & 0.1730 & 0.0220 \\
7.5 & Stanford and Smith & 0.4235 & 0.0824 & 0.0620 \\
7.5 & Cabrera & 0.6256 & 0.1797 & 0.1280 \\
7.5 & Juma & 0.3216 & 0.1876 & 0.0120 \\
15 & Stanford and Smith & 0.7274 & 0.1939 & 0.7220 \\
15 & Cabrera & 0.6247 & 0.2079 & 0.7020 \\
15 & Juma & 0.3421 & 0.2237 & 0.0100 \\
30 & Stanford and Smith & 0.5128 & 0.8778 & 0.6260 \\
30 & Cabrera & 0.2637 & 0.1472 & 0.0200 \\
30 & Juma & 0.3857 & 0.1469 & 0.0200 \\
\hline
\end{tabular}

Source: Elaborated by the authors (2019).

The estimates of parameters of models and their respective confidence intervals at 95\% probability are presented in Table 2 . The estimate of confidence interval of parameter $\mathrm{k}_{0}$ of the Cabrera model for the rates of $0,7.5$, and $15 \mathrm{~m}^{3} \mathrm{ha}^{-1}$ included the value zero. According to Zeviani et al. (2012), this result indicates that the parameter value is zero, therefore, the model did not fit for these treatments; when the parameter $\mathrm{k}_{0}$, is not considered, the model reduces itself to the Stanford and Smith model, with only one fraction of carbon (potentially mineralizable fraction). For the rate of 30 of the Cabrera model, the estimates of confidence intervals showed that all parameters of the model did not include the value zero, showing that the model describes the treatment, and the half-life time 
(v) of easily mineralizable carbon was estimated in 2.5 days (table 2). Only this treatment presented two mineralization phases, an easily mineralizable $\left(C_{1}\right)$ and a resistant phase $\left(k_{0}\right)$. Silva et al. (2019a) found that the Cabrera model was more adequate for the use of pig slurry at rates of $20 \mathrm{~m}^{3} \mathrm{ha}^{-1}$, incorporated to the soil; thus, the treatment presented two phases of carbon mineralization.

Table 2 - Estimates of the parameters of the models, and their respective asymptotic confidence intervals of 95\% ( $\mathrm{LL}=$ lower limit, and $\mathrm{UL}=$ upper limit) in the fit of mineralized $\mathrm{C}\left(\mathrm{mg} \mathrm{of} \mathrm{CO}_{2} \mathrm{~kg}^{-1}\right)$ of the evaluated treatments.

\begin{tabular}{|c|c|c|c|c|c|c|c|}
\hline \multicolumn{8}{|c|}{ Stanford and Smith Model } \\
\hline \multicolumn{4}{|c|}{ Rate 0} & \multicolumn{4}{|c|}{ Rate 7.5} \\
\hline $\begin{array}{l}\mathrm{C}_{0} \\
\mathrm{k} \\
\mathrm{v}\end{array}$ & $\begin{array}{l}\text { LL } \\
-- \\
--\end{array}$ & $\begin{array}{c}\text { Estimates } \\
-- \\
- \\
- \\
\end{array}$ & $\begin{array}{l}\text { UL } \\
-- \\
-- \\
--\end{array}$ & $\begin{array}{l}\mathrm{C}_{0} \\
\mathrm{k} \\
\mathrm{v}\end{array}$ & $\begin{array}{c}\mathrm{LL} \\
93.6419 \\
0.2499 \\
2.4772 \\
\end{array}$ & $\begin{array}{c}\text { Estimates } \\
94.9092 \\
0.2643 \\
2.6225 \\
\end{array}$ & $\begin{array}{c}\text { UL } \\
96.1986 \\
0.2798 \\
2.7736 \\
\end{array}$ \\
\hline \multicolumn{4}{|c|}{ Rate 15} & \multicolumn{4}{|c|}{ Rate 30} \\
\hline $\begin{array}{l}C_{0} \\
k \\
v\end{array}$ & $\begin{array}{l}\text { LL } \\
97.3797 \\
0.2627 \\
2.5159\end{array}$ & $\begin{array}{c}\text { Estimates } \\
97.9326 \\
0.2690 \\
2.5767\end{array}$ & $\begin{array}{c}U L \\
98.4894 \\
0.2755 \\
2.6385\end{array}$ & $\begin{array}{l}C_{0} \\
k \\
v\end{array}$ & $\begin{array}{c}\text { LL } \\
100.8229 \\
0.2586 \\
2.5586\end{array}$ & $\begin{array}{c}\text { Estimates } \\
101.4000 \\
0.2647 \\
2.6186\end{array}$ & $\begin{array}{l}\text { UL } \\
101.9444 \\
0.2709 \\
2.6803\end{array}$ \\
\hline
\end{tabular}

\begin{tabular}{|c|c|c|c|c|c|c|c|}
\hline \multicolumn{8}{|c|}{ Cabrera Model } \\
\hline \multicolumn{4}{|c|}{ Rate 0} & \multicolumn{4}{|c|}{ Rate 7.5} \\
\hline $\begin{array}{l}\mathrm{C}_{1} \\
\mathrm{k}_{0} \\
\mathrm{k}_{1}\end{array}$ & $\begin{array}{c}\mathrm{LL} \\
87.0386 \\
-0.2614 \\
0.2443\end{array}$ & $\begin{array}{c}\text { Estimates } \\
91.5985 \\
\mathbf{0 . 0 2 8 5} \\
0.2694\end{array}$ & $\begin{array}{c}U L \\
96.8376 \\
0.1813 \\
0.2964\end{array}$ & $\begin{array}{l}\mathrm{C}_{1} \\
\mathrm{k}_{0} \\
\mathrm{k}_{1}\end{array}$ & $\begin{array}{c}\mathrm{LL} \\
88.1567 \\
-0.0177 \\
0.2598\end{array}$ & $\begin{array}{c}\text { Estimates } \\
91.5890 \\
\mathbf{0 . 1 5 3 9} \\
0.2800\end{array}$ & $\begin{array}{c}U L \\
95.3962 \\
0.3129 \\
0.3013\end{array}$ \\
\hline $\mathrm{v}$ & 2.3386 & 2.5729 & 2.8372 & v & 2.3005 & 2.4755 & 2.6680 \\
\hline \multicolumn{4}{|c|}{ Rate 15} & \multicolumn{4}{|c|}{ Rate 30} \\
\hline $\begin{array}{l}\mathrm{C}_{1} \\
\mathrm{k}_{0} \\
\mathrm{k}_{1}\end{array}$ & $\begin{array}{c}L L \\
95.2927 \\
-0.1682 \\
0.2518\end{array}$ & $\begin{array}{c}\text { Estimates } \\
98.3546 \\
-0.0195 \\
0.2672\end{array}$ & $\begin{array}{c}\mathrm{UL} \\
101.6897 \\
0.1199 \\
0.2832\end{array}$ & $\begin{array}{l}\mathrm{C}_{1} \\
\mathrm{k}_{0} \\
\mathrm{k}_{1}\end{array}$ & $\begin{array}{r}\text { LL } \\
98.8410 \\
0.0548 \\
0.2692\end{array}$ & $\begin{array}{r}\text { Estimates } \\
100.0313 \\
0.0638 \\
0.2702\end{array}$ & $\begin{array}{r}\text { UL } \\
100.2218 \\
0.0726 \\
0.2711\end{array}$ \\
\hline v & 2.4476 & 2.5941 & 2.7528 & v & 2.5568 & $\begin{array}{r}2.5653 \\
-0.9544\end{array}$ & 2.5748 \\
\hline
\end{tabular}




\begin{tabular}{|c|c|c|c|c|c|c|c|}
\hline \multicolumn{8}{|c|}{ Juma Model } \\
\hline \multicolumn{4}{|c|}{ Rate 0} & \multicolumn{4}{|c|}{ Rate 7.5} \\
\hline $\begin{array}{l}\mathrm{C}_{0} \\
\mathrm{v} \\
\phi\end{array}$ & $\begin{array}{c}\mathrm{LL} \\
95.1644 \\
1.7842\end{array}$ & $\begin{array}{c}\text { Estimates } \\
105.4848 \\
3.0315 \\
0.3152\end{array}$ & $\begin{array}{c}\text { UL } \\
115.8052 \\
4.2789\end{array}$ & $\begin{array}{l}\mathrm{C}_{0} \\
\mathrm{v} \\
\phi\end{array}$ & $\begin{array}{c}\mathrm{LL} \\
101.679 \\
2.1089\end{array}$ & $\begin{array}{c}\text { Estimates } \\
110.0563 \\
3.0908 \\
0.3056\end{array}$ & $\begin{array}{c}\text { UL } \\
118.4334 \\
4.0727\end{array}$ \\
\hline \multicolumn{4}{|c|}{ Rate 15} & \multicolumn{4}{|c|}{ Rate 30} \\
\hline $\begin{array}{l}C_{0} \\
v \\
\phi\end{array}$ & $\begin{array}{c}\mathrm{LL} \\
102.9182 \\
1.8619\end{array}$ & $\begin{array}{c}\text { Estimates } \\
113.4426 \\
3.0481 \\
0.3190\end{array}$ & $\begin{array}{c}U L \\
123.9671 \\
4.2344\end{array}$ & $\begin{array}{l}\mathrm{C}_{0} \\
\mathrm{v} \\
\phi\end{array}$ & $\begin{array}{c}\mathrm{LL} \\
107.5219 \\
1.9906\end{array}$ & $\begin{array}{c}\text { Estimates } \\
117.7371 \\
3.1155 \\
0.2985\end{array}$ & $\begin{array}{c}\text { UL } \\
127.9524 \\
4.2403\end{array}$ \\
\hline
\end{tabular}

Source: Elaborated by the authors (2019).

The Stanford and Smith model fitted to the rates of 7.5, 15.0, and $30.0 \mathrm{~m}^{3} \mathrm{ha}^{-1}$, and the Juma model fitted to the data of the four treatments, since the estimates of confidence intervals showed that all parameters of the model did not include the value zero.

Considering the confidence intervals to estimate the parameter $\mathrm{C}_{0}$ in the Stanford and Smith model, there was no superposition between confidence intervals in the treatments with rates of 7.5, 15.0, and $30.0 \mathrm{~m}^{3} \mathrm{ha}^{-1}$. Thus, the rate of $30.0 \mathrm{~m}^{3} \mathrm{ha}^{-1}$ presented higher potentially mineralizable carbon than the rates of 15.0 and $7.5 \mathrm{~m}^{3} \mathrm{ha}^{-1}$; and the rate of $15.0 \mathrm{~m}^{3}$ ha-1 had higher potentially mineralizable carbon than the rate of $7.5 \mathrm{~m}^{3} \mathrm{ha}^{-1}$. These results were expected, since a higher rate can stimulate the microbial activity, increasing the mineralization of the carbon added to the soil and the degradation of the native soil organic matter (FERNANDES et al., 2011). Despite the differences in amount of potentially mineralizable carbon $\left(\mathrm{C}_{0}\right)$, the parameter half-life time $(\mathrm{v})$ of all treatments in the Stanford and Smith model had superposition of confidence intervals, showing that all treatments needed approximately 2.6 days to mineralize half of the potentially mineralizable carbon.

Superposition was found in the Juma model when considering the confidence intervals for the estimate of the parameter $\mathrm{C}_{0}$ in all treatments; thus, all treatments presented the same amount of potentially mineralizable carbon. Although the amount of carbon added was different, this factor alone does not totally explain the complexity in the soil ecosystem, where several other factors, such as $\mathrm{C}$ to $\mathrm{N}$ ratio and the type of $\mathrm{N}$ ions, can affect the carbon mineralization by microorganisms (FERNANDES et al., 2011). Superposition was found between the confidence intervals of the parameter half-life time (v) in all treatments of the model; as well as the Stanford and Smith model, this indicates that all treatments needed approximately 3 days to decompose half of the potentially mineralizable carbon.

All models presented, in general, good fit in all treatments, since the values of the adjusted coefficient of determination $\left(\mathrm{R}^{2}{ }_{\text {aj }}\right.$ ) were above 94\% (TABLE 3). The fits are shown in Figures 1 to 4 . Silva et al. (2019a) studied the fit of the nonlinear models (Stanford and Smith, and Cabrera) for carbon mineralization from pig slurry and oat plant residues in soils and found $\mathrm{R}^{2}$ aj values higher than 0.97 , indicating that the models describe adequately the data. For the rate of 0 , Juma was the only model that described the carbon mineralization. For the rates of 7.5 and $15.0 \mathrm{~m}^{3} \mathrm{ha}^{-1}$, Stanford and Smith was the model that best described the carbon mineralization, which presented lower AIC values and higher $\mathrm{R}^{2}$ aj values than the Juma model. For the rate of $30.0 \mathrm{~m}^{3} \mathrm{ha}^{-1}$, Cabrera was the model that best described the carbon mineralization, presenting the lowest $\mathrm{AIC}$ and the highest $\mathrm{R}^{2}{ }_{\mathrm{aj}}$, followed by the Stanford and Smith model and Juma model. 
Table 3 - Estimates of selection criteria: adjusted coefficient of determination $\left(\mathrm{R}^{2}\right.$ ) and Akaike information criterion (AIC) for the fitted models for the description of mineralized carbon ( $\mathrm{mg} \mathrm{CO}_{2} \mathrm{~kg}^{-1}$ ) of the evaluated treatments.

\begin{tabular}{llll}
\hline \multicolumn{1}{c}{ Treatments } & \multicolumn{1}{c}{ Model } & \multicolumn{2}{c}{ Selection criteria } \\
\hline \multirow{2}{*}{ Rate 0 } & Stanford and Smith & $\mathrm{R}^{2}{ }_{\text {aj }}$ & AIC \\
& Cabrera & 0.9993 & 12.4458 \\
& Juma & 0.9992 & 14.1103 \\
Rate 7.5 & Stanford and Smith & 0.9482 & 39.5166 \\
& Cabrera & 0.9988 & 16.9311 \\
Rate 15.0 & Juma & 0.9995 & 11.0225 \\
& Stanford and Smith & 0.9701 & 36.9607 \\
Cabrera 30.0 & 0.9997 & 7.1026 \\
& Juma & 0.9997 & 8.7364 \\
& Stanford and Smith & 0.9544 & 39.6909 \\
& Cabrera & 0.9998 & 7.1097 \\
\hline
\end{tabular}

Source: Elaborated by the authors (2019).

Figure 1 - Fitted model for carbon mineralization ( $\mathrm{mg}$ of $\left.\mathrm{CO}_{2} \mathrm{~kg}^{-1}\right)$ as a function of time of incubation, at the rate of $0 \mathrm{~m}^{3}$ ha-1 of pig slurry.

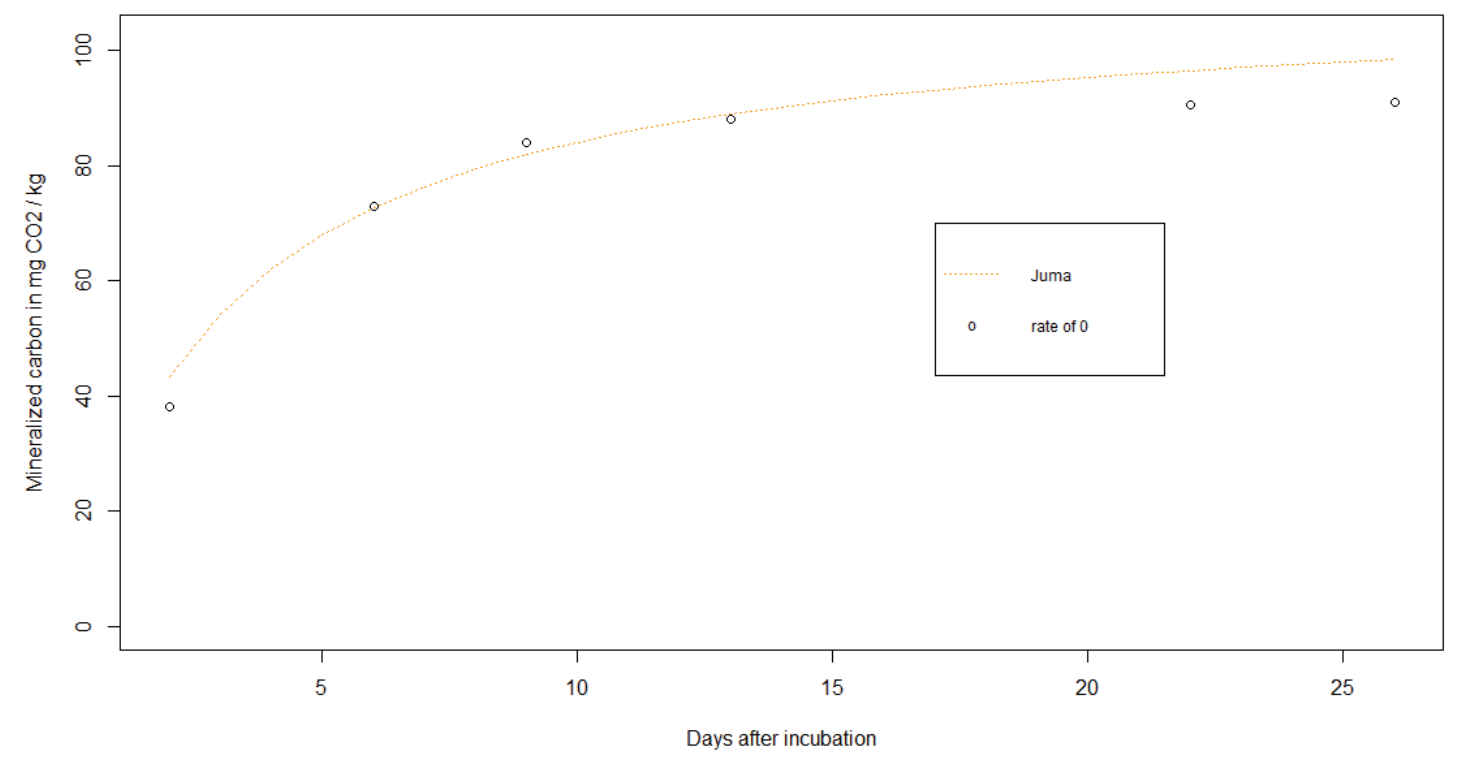

Source: Elaborated by the authors (2019). 
Figure 2 - Fitted model for carbon mineralization ( $\mathrm{mg}$ of $\mathrm{CO}_{2} \mathrm{~kg}^{-1}$ ) as a function of time of incubation, at the rate of $7.5 \mathrm{~m}^{3}$ ha-1 of pig slurry.

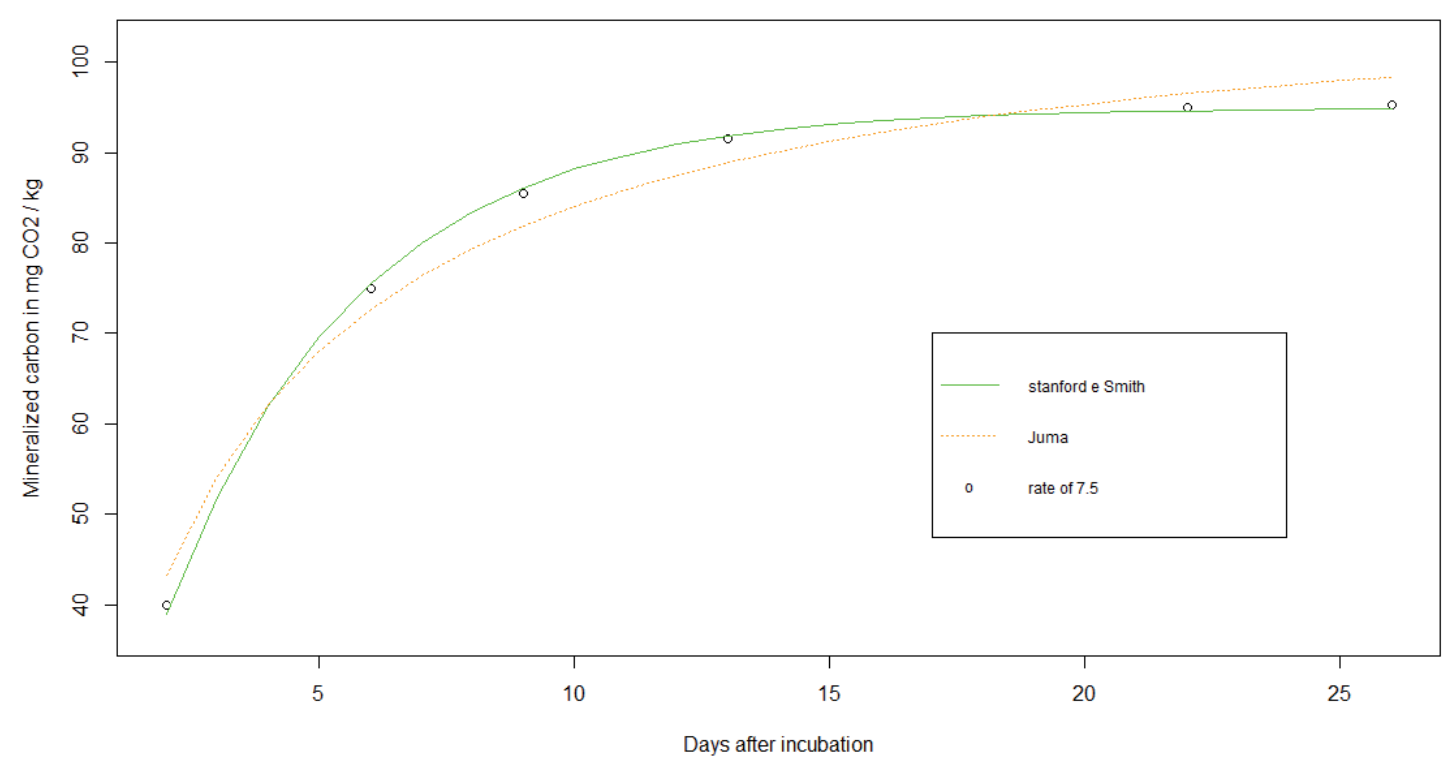

Source: Elaborated by the authors (2019).

Figure 3 - Fitted model for carbon mineralization ( $\mathrm{mg}$ of $\mathrm{CO}_{2} \mathrm{~kg}^{-1}$ ) as a function of time of incubation, at the rate of $15.0 \mathrm{~m}^{3} \mathrm{ha}^{-1}$ of pig slurry.

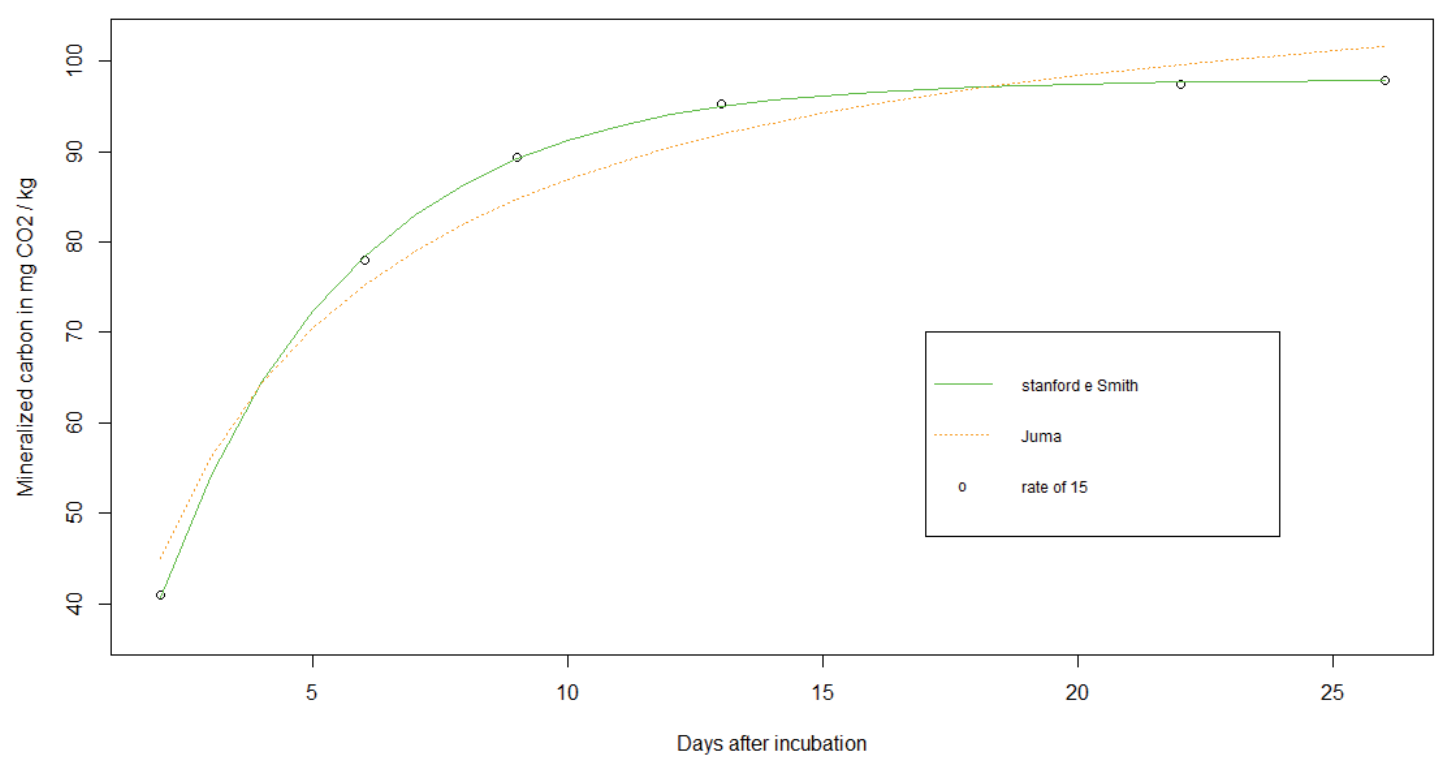

Source: Elaborated by the authors (2019). 
Figure 4 - Fitted model for carbon mineralization ( $\mathrm{mg}$ of $\mathrm{CO}_{2} \mathrm{~kg}^{-1}$ ) as a function of time of incubation, at the rate of $30.0 \mathrm{~m}^{3} \mathrm{ha}^{-1}$ of pig slurry.

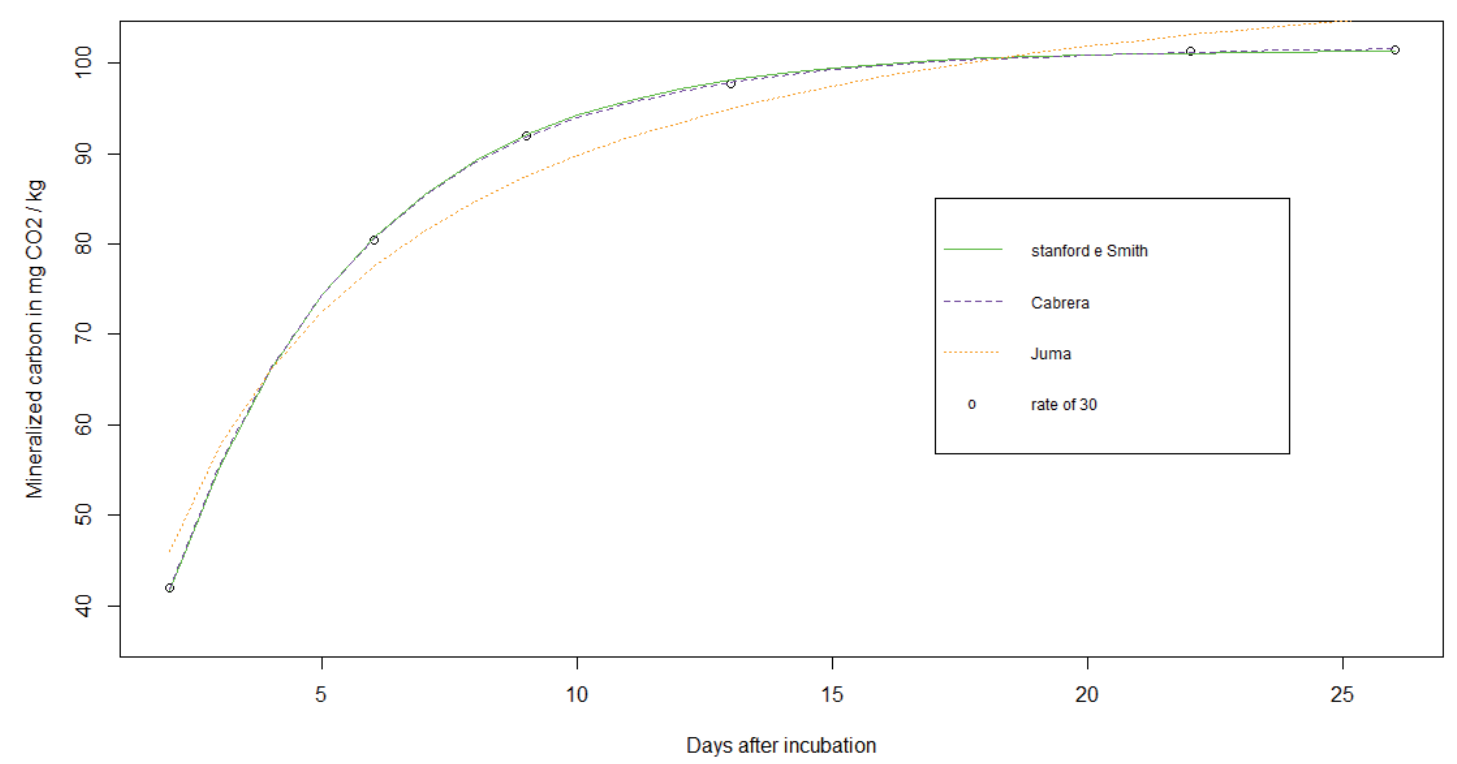

Source: Elaborated by the authors (2019).

\section{Conclusions}

Juma was the most adequate model for the description of carbon mineralization in the treatment with pig slurry at rate of $0 \mathrm{~m}^{3} \mathrm{ha}^{-1}$, thus, this treatment presents only one fraction of carbon that is mineralizable.

Stanford and Smith was the best model for the description of carbon mineralization in the treatments with pig slurry at rates of $7.5 \mathrm{~m}^{3} \mathrm{ha}^{-1}$ and $15 \mathrm{~m}^{3}$ ha-1, i.e., these treatments presented only carbon fractions that are exponentially mineralized.

Cabrera was the most adequate model to describe carbon mineralization in the treatment with pig slurry at rate of $30.0 \mathrm{~m}^{3} \mathrm{ha}^{-1}$, thus, this treatment certainly presents fractions of mineralizable carbon with exponential behavior, and more resistant fractions with constant mineralization.

\section{Comparação de modelos não lineares na descrição da mineralização do carbono no solo tratado com dejetos de suínos}

\section{Resumo}

Uma estratégia para reduzir os impactos ambientais causados por dejetos de suínos consiste em utilizar esses resíduos em solos para produção de culturas agrícolas. Por meio das curvas de mineralização de carbono é possível determinar os melhores períodos para utilização da matéria orgânica visando ao manejo adequado do solo e das culturas. Objetivou-se com este estudo comparar 
o ajuste de modelos não lineares que descrevem a mineralização de carbono no solo. 0 experimento foi realizado usando o delineamento blocos ao acaso com quatro repetições e quatro tratamentos. Foram usados os seguintes tratamentos: sem adição (0), doses mensais de 7,5; 15,0 e 30,0 m $\mathrm{ha}^{-1}$ de dejetos de suínos. As amostras de solo coletadas foram incubadas por 26 dias e foram feitas sete observações do volume de carbono mineralizado ao longo do tempo. A descrição da mineralização do carbono foi feita pelos modelos Stanford e Smith, Cabrera e Juma, considerando estrutura de erros autorregressivos AR (1) quando necessário. Para comparar os ajustes foi utilizado o critério de informação Akaike (AIC). Em geral, a descrição da mineralização de carbono nos tratamentos pelos modelos não lineares foi adequada. 0 modelo Juma foi o mais adequado para descrever o tratamento de dose 0 . O modelo Stanford e Smith foi o mais adequado para descrever os tratamentos de dose 7,5 e 15,0 $\mathrm{m}^{3}$ ha-1. O modelo Cabrera foi o mais adequado para descrever o tratamento de dose $30,0 \mathrm{~m}^{3} \mathrm{ha}^{-1}$.

Palavras-chave: Resíduo orgânico. Modelo Stanford e Smith. Modelo Cabrera. Modelo Juma.

\section{References}

BARreto, P. A. B.; ROdRIGUeS, E. F. G.; ROdRigueS, A. C. G.; BARROS, N. F.; ALVES, B. J. R.; FONSECA, S. Mineralização de nitrogênio e carbono em solos sob plantações de eucalipto, em uma sequência de idades. Revista Brasileira de Ciência do Solo, Viçosa, v. 34, n. 3, p. 735-745, jun. 2010. Disponível em: http://www.scielo.br/scielo.php?script=sci_arttext\&pi$d=$ S0100-06832010000300015\&lng=en\&nrm=iso. Acesso em: 14 jan. 2019.

BISON PINTO, M. A.; FABBRIS, C.; BASSO, C. J.; SANTI, A. L.; GIROTTO, E. Aplicação de dejeto líquido de suínos e manejo do solo na sucessão aveia/milho. Pesquisa Agropecuária Tropical, Goiânia, v. 44, n. 2, p. 205-212, abr./jun. 2014. Disponível em: https://www.revistas.ufg.br/pat/article/ view/25759/16779. Acesso em: 14 jan. 2019.

CABRERA, M. L. Modeling the flush of nitrogen mineralization caused by drying and rewetting soils. Soil Science Society of America Jornal, v. 57, p. 63-66, 1993.

CADONÁ, E. A. Contaminação da água pelo uso agrícola de dejetos de suínos na bacia hidrográfica rio coruja/bonito, braço do Norte/SC. 2017. 127 p. Dissertação (Mestrado). Universidade Federal de Santa Catarina, Florianópolis.

CARNEIRO, A. P. S.; MUNIZ, J.A; CARNEIRO, P.L.S; MALHADO, C.H.M.M; MARTINS FILHO, R.; SILVA, F.F. Identidade de modelos não lineares para comparar curvas de crescimento de bovinos da raça Tabapuã. Pesquisa Agropecuária Brasileira, Brasília, v. 49, n. 1, p. 57-62, 2014. Disponível em: https://seer.sct.embrapa.br/index.php/pab/article/view/18183. Acesso em: 14 jan 2019.

CONAB, Companhia Nacional de Abastecimento. Análise mensal de carne suína, dezembro/2017, 5 p. Disponível em: https://www.conab.gov.br/info-agro/analises-do-mercado-agropecuario-e-extrativista/analises-do-mercado/historico-mensal-de-carne-suina. Acesso em: 14 jan 2020. 
DRAPER, N. R.; SMITH, H. Applied regression analisys. 3rd ed., reprint. New York: J. Wiley; 2014.

FERNANDES, A. H. B. M.; CARDOSO, M. A.; SOUZA, R. A. C.; FERNANDES, F. A.; SOARES, M. T. S.; CRISPIM, S. M. A.; GALVANI, F.; LISITA, F. O. Nitrificação e Mineralização de Carbono em Solos Tratados com Dejetos de Suínos Biodigeridos. Corumbá: Embrapa Pantanal, 2011.

FURTADO, T. D. R.; MUNIZ, J. A.; SILVA, E. M.; FERNANDES, J. G. Drying kinetics of jabuticaba pulp by regression models. Revista Brasileira de Fruticultura, Jaboticabal, v. 41, n. 1, p. e-097, 2019.

GUEdeS, M. H. P.; MUNIZ, J. A.; PEREZ, J. R. O.; SILVA, F. F.; AQUINO, L. H.; SANTOS, C. L. Estudo das curvas de crescimento de cordeiros das raças Santa Inês e Bergamácia considerando Heterogeneidade de variâncias. Ciência e Agrotecnologia, Lavras, v. 28, n. 2, p. 381388, mar./abr. 2004. Disponível em: http://www.scielo.br/scielo.php?script=sci_arttext\&pi$d=$ S1413-70542004000200019\&Ing=en\&nrm=iso. Acesso em: 15 jan. 2019.

GUIMARÃES, D. D.; AMARAL, G. F.; MAIA, G. B. S.; LEMOS, M. L. F.; ITO, M.; CUSTODIO, S. Suinocultura: estrutura da cadeia produtiva, panorama do setor no brasil e no mundo e o apoio do BNDES. Agroindústria, 2017.

JUMA, N. G.; PAUL, E. A.; MARY, B. Kinetic analysis of net mineralization in soil. Soil Science Society of America Journal, v. 48, p. 465-472, 1984.

MARTINES, A. M.; ANDRADE, C. A.; CARDOSO, E. J. B. N. Mineralização do carbono orgânico em solos tratados com lodo de curtume. Pesquisa Agropecuária Brasileira, Brasília, v. 41, n. 7, p. 1149-1155, jul. 2006. Disponível em: http://www.scielo.br/scielo.php?script=sci_arttext\&pid=S0100-204X2006000700011\&lng=en\&nrm=iso. Acesso em: 14 jan. 2019.

MAZZINI, A. R. A.; MUNIZ, J. A.; AQUINO, L. H.; SILVA, F. F. Análise da curva de crescimento de machos Hereford. Ciência e Agrotecnologia, Lavras, v. 27, n. 5, p. 1105-1112, 2003.

MENDES, P. N.; MUNIZ, J. A.; SILVA, F. F.; MAZZINI, A. R. A. Modelo Logístico difásico no estudo do crescimento de fêmeas da raça Hereford. Ciência Rural, Santa Maria, v. 38, n. 7, p. 1984-1990, 2008.

MUIANGA, C. A.; MUNIZ, J. A.; NASCIMENTO, M. S.; FERNANDES, T. J.; SAVIAN, T. V. Descrição da curva de crescimento de frutos do cajueiro por modelos não lineares. Revista Brasileira de Fruticultura, Jaboticabal, v. 38, n. 1, p. 22-32, 2016.

MUNIZ, J. A.; NASCIMENTO, M. S.; FERNANDES, T. J. Nonlinear models for description of cacao fruit growth with assumption violations. Revista Caatinga, Mossoró, v. 30, n. 1, p. 250-257, 2017.

PEREIRA, J. M.; MUNIZ, J. A.; SILVA, C. A. Nonlinear models to predict nitrogen mineralization in an Oxisol. Scientia Agricola, Piracicaba, v. 62, n. 4, p. 395-400, ago. 2005 . Disponível em: http:// www.scielo.br/scielo.php?script $=$ sci_arttext\&pid $=$ S0103-90162005000400014\&lng $=$ en\&nrm $=i-$ so. Acesso em: 15 jan. 2019. 
PEREIRA, J. M.; MUNIZ, J. A.; SAFADI, T.; SILVA, C. A. Comparação entre modelos para predição do nitrogênio mineralizado: uma abordagem bayesiana. Ciência e Agrotecnologia. Lavras, v. 33, p. 1792-1797, 2009.

PEREIRA, M. S. Avaliação das taxas de mineralização de carbono e nitrogênio do composto orgânico proveniente de carcaça e despojo de pequenos ruminantes. 2014. 48 p. Dissertação (Mestrado). Universidade Federal do Ceará, Fortaleza.

PRADO, T. K. L.; SAVIAN, T. V.; MUNIZ, J. A. Ajuste dos modelos Gompertz e Logístico aos dados de crescimento de frutos de coqueiro anão verde. Ciência Rural, Santa Maria, v. 43, n. 5, p. 803-809, maio 2013.

RIBEIRO, T. D.; SAVIAN, T. V.; FERNANDES, T. J.; MUNIZ, J. A. The use of the nonlinear models in the growth of pears of 'Shinseiki' cultivar. Ciência Rural, Santa Maria, v. 48, n. 1, e20161097, jan. 2018 (a). Disponível em: http://dx.doi.org/10.1590/0103-8478cr20161097. Acesso em: 16 jan. 2019.

RIBEIRO, T. D.; PACOPAHYBA, R. W. M.; MORAIS, A. R.; MUNIZ, J. M. Description of the growth of pequi fruits by nonlinear models. Revista Brasileira de Fruticultura, Jaboticabal, v. 40, n. 4, p. e-949 , 2018 (b). Disponível em: http://dx.doi.org/10.1590/0100-29452018949. Acesso em: 16 jan. 2019.

SAVIAN T. V.; MUNIZ, J. A. A Study of in situ degradability: Heterogeneity of variances and correlated errors. Scientia Agrícola, Piracicaba, v. 64, p. 548-554, 2007. Disponível em: https://doi.org/10.15 90\%2Fs0103-90162007000500013. Acesso em: 16 jan. 2019.

SILVA, D. A. P. Mineralização da matéria orgânica de lodo aplicado no solo e produtividade do capim-tifton 85. 2017. 92 p. Dissertação (Mestrado). Universidade Federal de Minas Gerais, Belo Horizonte.

SILVA, D. M.: ANTONIOLLI, Z. I.; JACQUES, R. J. S.; SILVEIRA, A. O.; SILVA, D. A. A.; RACHE, M. M.,; PASSOS, V. H. G.; SILVA, B. R. Indicadores Microbiológicos de Solo em Pastagem com Aplicação Sucessiva de Dejetos de Suínos. Revista Brasileira de Ciência do Solo, Viçosa, v. 39, n. 6, p. 1585-1594, dez. 2015. Disponível em: http://www.scielo.br/scielo.php?script=sci_arttext\&pi$d=$ S0100-06832015000601585\&lng=en\&nrm=iso. Acesso em: 14 jan. 2019.

SILVA, E. M.; RIBEIRO, T. D.; FERNANDES, J. G.; MUNIZ, J. A. Descrição da mineralização do carbono de dejetos de suíno e palha de aveia no solo por modelos não lineares. Revista Agrogeoambiental, Pouso Alegre, v. 11, p. 210-225, 2019a. Disponível em: https://agrogeoambiental.ifsuldeminas. edu.br/index.php/Agrogeoambiental/article/view/1299/pdf_1. Acesso em: 14 jan. 2020

SILVA, E. M.; SILVEIRA, S. C.; RIBEIRO, T. D.; MUNIZ, J. A. Descrição da decomposição do lodo de esgoto e palha de aveia por modelos não lineares. Revista Agrogeoambiental, Pouso Alegre, v. 11, p. 153-164 , 2019b. Disponível em: https://agrogeoambiental.ifsuldeminas.edu.br/index.php/ Agrogeoambiental/article/view/1287/pdf_1. Acesso em: 14 jan. 2020 
SILVEIRA, S. C.; MUNIZ, J. A.; SOUSA, F. A.; CAMPOS, A. T. Modelos não lineares ajustados à produção acumulada de biogás provenientes de camas sobrepostas de suínos. Revista Agrogeoambiental, Pouso Alegre, v. 10, n. 3, p. 91-103, jul./set. Disponível em: https://agrogeoambiental.ifsuldeminas. edu.br/index.php/Agrogeoambiental/article/view/1168. Acesso em: 14 jan. 2019.

STANFORD, G.; SMITH, S. J. Nitrogen mineralization potentials of soil. Soil Science Society of America Journal, v. 36, p. 465-471, 1972.

SOUSA, I. F.; KUNZLE NETO, J. E.; MUNIZ, J. A.; GUIMARÃES, R. M.; SAVIAN, T. V.; MUNIZ, F. R. Fitting nonlinear autoregressive models to describe coffee seed germination. Ciência Rural, Santa Maria, v. 44, p. 2016-2021, 2014.

ZEVIANI, W. M.; SILVA, C. A.; CARNEIRO, W. J. O.; MUNIZ, J. A. Modelos não lineares para a liberação de potássio de estercos animais em latossolos. Ciência Rural, Santa Maria, v. 42, n. 10, p. 1789-1796, out., 2012. Disponível em: http://www.scielo.br/pdf/cr/v42n10/a28712cr3006.pdf. Acesso em: 15 jan. 2019.

Received: February 27, 2019

Accepted: May 10, 2019 